\title{
Dampak Kebijakan Tarif terhadap Sektor Pertanian di Indonesia: Analisis Model Global Trade Analysis Project (GTAP)
}

\author{
Kartini $^{\mathrm{a}, *}$, \& Silvia Margaret ${ }^{\mathrm{a}}$ \\ ${ }^{a}$ Universitas Gadjah Mada, Yogyakarta
}

\begin{abstract}
This study aims to investigate the impact of implementing tariff in the Indonesian agriculture sector using the GTAP model. We study the impact of enacting tariffs on GDP, trade balance, welfare, terms of trade, aggregate exports, world trade patterns, and labor-market changes in Indonesia. Our simulation results suggest that imposing an import tariff rate of 7,5\% can raise GDP, trade balance, welfare and terms of trade. The zero-tariff rate simulation also suggests that imports, exports, world trade, and labor-market changes in Indonesia could exert positive impacts on the agriculture sector. The implication of our study is that tariff policies pursued by policy makers may well depend on the country's main goal.
\end{abstract}

Keywords: trade policy; tariff; GTAP model; CGE analysis

\begin{abstract}
Abstrak
Paper ini bertujuan untuk melihat dampak yang ditimbulkan adanya kebijakan pengenaan tarif pada sektor pertanian di Indonesia. Model GTAP diimplementasikan untuk melihat dampak yang ditimbulkan pada PDB, neraca perdagangan, kesejahteraan, terms of trade, nilai impor, nilai ekspor, pola perdagangan dunia, dan perubahan pada sektor tenaga kerja di Indonesia. Hasil simulasi kebijakan menjelaskan bahwa adanya pengenaan tarif impor sebesar 7,5\% dapat meningkatkan PDB, neraca perdagangan, kesejahteraan, dan terms of trade. Hasil simulasi dengan pengenaan tarif sebesar $0 \%$ juga menjelaskan bahwa nilai impor, nilai ekspor, perdagangan dunia, dan perubahan pada sektor tenaga kerja memiliki dampak positif terhadap sektor pertanian. Disimpulkan bahwa kebijakan tarif yang diambil tergantung pada tujuan utama yang ingin diperoleh oleh suatu negara.
\end{abstract}

Kata Kunci: kebijakan perdagangan; tarif; model GTAP; analisis CGE Kode Klasifikasi JEL: F13, F47, C68

*Alamat Korespondensi Penulis: Bulaksumur, Caturtunggal, Kec. Depok, Kabupaten Sleman Daerah Istimewa Yogyakarta 55281. E-mail: tini.031196.kt@gmail.com. 


\section{Pendahuluan}

Indonesia sebagai negara agraris tentu masih bergantung pada sektor pertanian sebagai salah satu penopang perekonomian. United Nations (2017) dalam publikasi Kementerian Pertanian (2020) menyatakan bahwa pertanian mempunyai peranan penting dalam kehidupan manusia karena berfungsi sebagai penyedia pangan, pakan untuk ternak, dan bioenergi. Peran pertanian sangat strategis dalam mendukung perekonomian nasional, terutama mewujudkan ketahanan pangan, peningkatan daya saing, penyerapan tenaga kerja, dan penanggulangan kemiskinan. Berdasarkan Rencana Strategis Kementerian Pertanian 2020-2024, kontribusi sektor pertanian terhadap PDB Indonesia selama kurun waktu 2015-2019 menunjukkan tren pertumbuhan yang cukup signifikan. Pada tahun 2017 dan 2018, pertumbuhan PDB mencapai 3,6\%, naik cukup tinggi jika dibandingkan pada tahun 2015 yang hanya tumbuh 3\%. Tetapi pada tahun 2019, terjadi penurunan pertumbuhan dikarenakan penurunan laju peningkatan produksi pangan akibat musim kemarau yang panjang. Hal ini diikuti dengan data terbaru yang dirilis oleh Badan Pusat Statistik (2020) yang menjelaskan bahwa terjadi penurunan impor menurut golongan barang ekonomi untuk bahan baku sebesar 70,42\%, barang konsumsi sebesar 13,09\%, dan barang modal sebesar 16,49\% pada Juni 2020.

Publikasi Badan Pusat Statistik (2020a) dalam survei sosial demografi dampak pandemi COVID-19 menyatakan bahwa 51\% responden menjadikan bahan makanan sebagai perubahan pengeluaran yang paling dominan pada Juni 2020. Hal ini membuktikan pentingnya peranan sektor pertanian dalam memenuhi kebutuhan masyarakat. Salah satu hal yang membantu dalam pemenuhan kebutuhan pada sektor pertanian adalah impor dari negara lain. Adapun data impor sektor pertanian dapat dilihat pada Gambar 1.

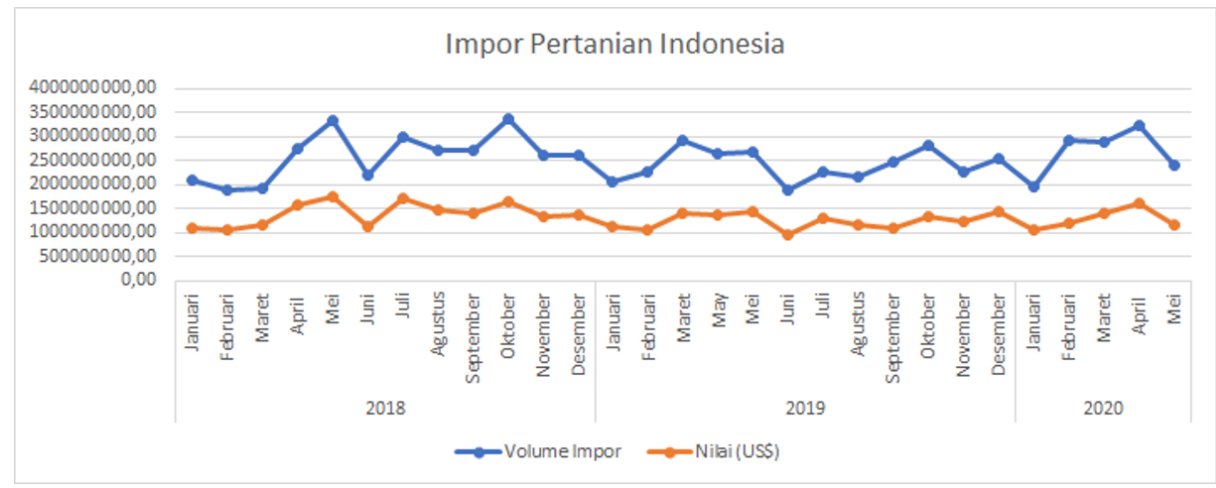

Gambar 1: Impor Sektor Pertanian Indonesia

Sumber: Kementerian Pertanian (2020) 
Gambar 1 menjelaskan bahwa pada bulan Januari 2020 terjadi penurunan pada nilai impor Indonesia, hal ini disebabkan oleh nilai impor dari Tiongkok yang menurun akibat pandemi COVID-19 yang muncul pada Desember 2019. Sebagaimana diketahui bahwa salah satu negara pengimpor terbesar Indonesia adalah Tiongkok. Hal ini dijelaskan oleh data pada Tabel 1.

Tabel 1: Lima Negara Mitra Impor Indonesia Tahun 2016-2020

\begin{tabular}{cccccc}
\hline \hline No & 2016 & 2017 & 2018 & 2019 & 2020 \\
\hline 1 & Tiongkok & Tiongkok & Tiongkok & Tiongkok & Tiongkok \\
2 & Singapura & Singapura & Singapura & Singapura & Jepang \\
3 & Jepang & Jepang & Jepang & Jepang & Singapura \\
4 & Malaysia & Malaysia & Thailand & Malaysia & Thailand \\
5 & Thailand & Thailand & Amerika Serikat & Thailand & Amerika Serikat \\
\hline Sumber: World Integrated Trade Solution (WITS) (2020) \& BPS (2020b)
\end{tabular}

Selama lima tahun terakhir Tiongkok menempati peringkat pertama sebagai negara pengimpor terbesar dari Indonesia dan diikuti oleh lima negara lainnya, yakni Singapura, Jepang, Malaysia, Thailand, dan Amerika Serikat. Hal ini juga dapat dilihat dari data terbitan terakhir oleh WITS yang berakhir pada tahun 2018 dan dijelaskan pada Gambar 2.

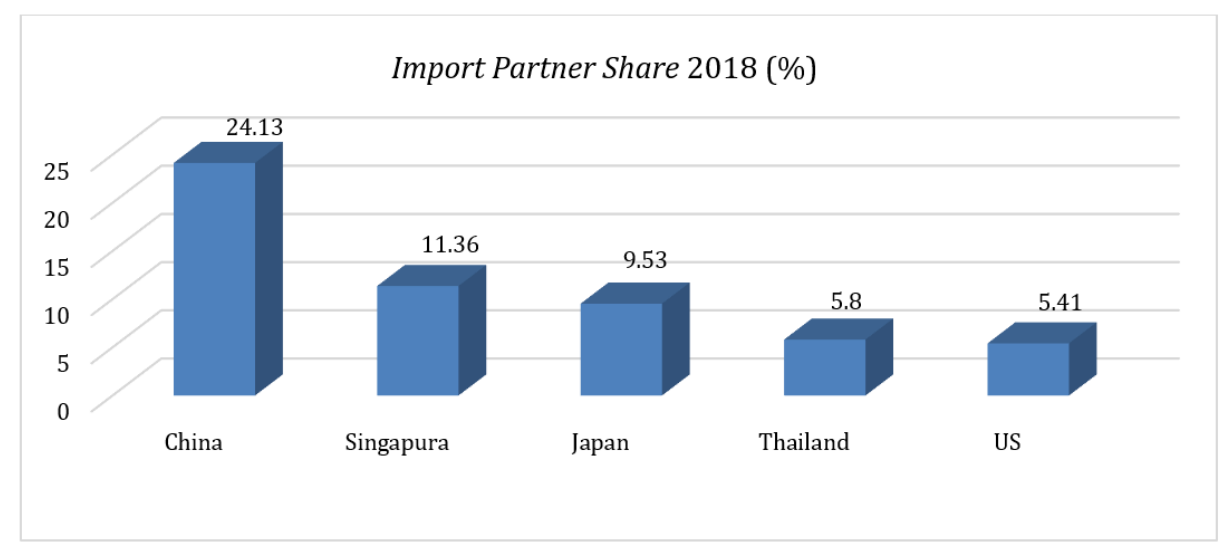

Gambar 2: Pangsa Impor dari Negara Mitra 2018

Sumber: WITS (2020)

Gambar 2 menjelaskan bahwa Tiongkok merupakan asal negara impor terbesar ke Indonesia. Hal inilah yang menyebabkan impor Indonesia menurun pada Januari 2020 dimana kasus pertama COVID-19 muncul pada Desember 2019 di Tiongkok. Munculnya pandemi COVID-19 berdampak terhadap turunnya impor Indonesia. Mckibbin \& Fernando (2020) mengungkapkan bahwa di tengah pandemi COVID-19 konsumsi rumah tangga Indonesia untuk sektor pertanian diprediksi akan menurun sebesar 8,29\% dari angka seharusnya jika tidak adanya 
pandemi COVID-19. Kondisi tersebut menjadi kendala pada produksi sektor pertanian domestik yang diprediksi akan menurun sebesar 6,20\%.

Adapun hal lain yang diperhatikan selain impor adalah ekspor Indonesia pada sektor pertanian yang juga cenderung mengalami penurunan dari bulan Maret hingga Mei 2020. Hal ini juga dibuktikan oleh penelitian Fugazza (2020) yang menyimpulkan bahwa salah satu penyebab penurunan ekspor adalah pandemi COVID-19 yang telah menurunkan total ekspor komoditi ke Tiongkok sebesar 15,5 hingga 33,1 miliar dolar Amerika Serikat. Penurunan total ekspor ini juga mampu mengurangi proyeksi pertumbuhan tahunan hingga 46\%. Penurunan ekspor ini merupakan efek dari adanya peningkatan kasus COVID-19 di berbagai negara yang juga cenderung meningkat hingga saat ini. Penurunan ekspor sektor pertanian dapat dilihat pada Gambar 3.

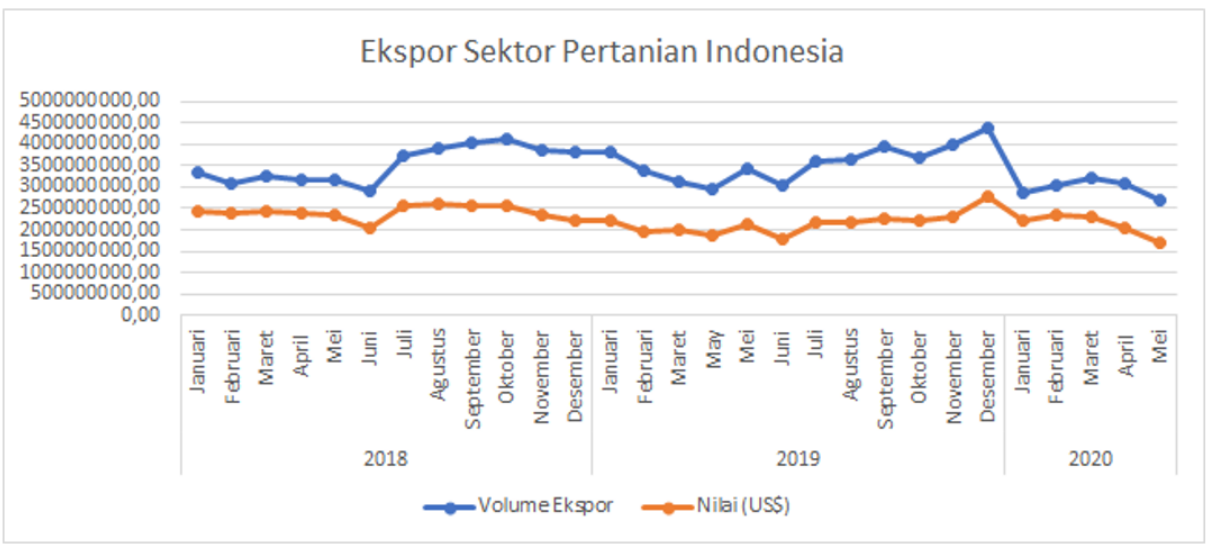

Gambar 3: Ekspor Sektor Pertanian Indonesia

Sumber: Kementerian Pertanian (2020)

Kemampuan Indonesia untuk memenuhi kebutuhan masyarakat menjadi sangat sulit dikarenakan nilai impor pertanian yang juga menurun, sehingga pemerintah fokus pada pemenuhan kebutuhan masyarakat dan mengurangi ekspor sektor pertanian. Hal ini menyebabkan dampak lain kepada negara lain yang menjadi mitra perdagangan Indonesia. Beberapa negara yang menjadi mitra ekspor Indonesia dijelaskan pada Tabel 2.

Tabel 2 menjelaskan lima negara mitra ekspor Indonesia selama tahun 20162020. Hasil serupa dari data yang ditemukan menjelaskan bahwa Tiongkok merupakan negara mitra ekspor terbesar Indonesia. Hal ini dapat secara rinci dijelaskan oleh Gambar 4.

Data pada Gambar 4 menjelaskan bahwa Tiongkok merupakan negara tujuan ekspor terbesar Indonesia. Adanya berbagai permasalahan yang timbul baik dari sisi impor dan ekspor mendorong pemangku kebijakan untuk memilih kebijakan yang tepat untuk Indonesia. Salah satu kebijakan yang dapat digunakan untuk 
Tabel 2: Lima Negara Mitra Ekspor Indonesia Tahun 2016-2020

\begin{tabular}{cccccc}
\hline \hline No & 2016 & 2017 & 2018 & 2019 & 2020 \\
\hline 1 & Tiongkok & Tiongkok & Tiongkok & Tiongkok & Tiongkok \\
2 & Amerika Serikat & Amerika Serikat & Jepang & Jepang & Jepang \\
3 & Jepang & Jepang & Amerika Serikat & Amerika Serikat & Amerika Serikat \\
4 & Singapura & India & India & India & India \\
5 & India & Singapura & Singapura & Singapura & Singapura \\
\hline
\end{tabular}

Sumber: WITS (2020) \& BPS (2020b)

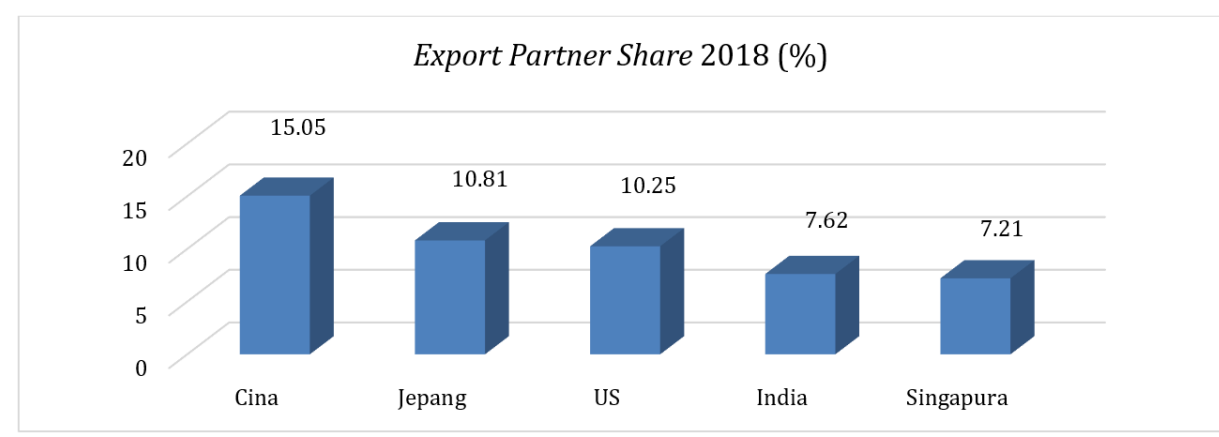

Gambar 4: Pangsa Ekspor ke Negara Mitra 2018 Sumber: WITS (2020)

mengatasi permasalahan yang timbul akibat penurunan impor adalah dengan menghapus hambatan dagang pangan dan komoditas pertanian dengan mengeliminasi tarif dan melonggarkan persyaratan Surat Persetujuan Impor (SPI) untuk impor sektor pertanian. Hal ini sesuai dengan penelitian yang dilakukan oleh Amanta \& Aprilianti (2020) yang memprediksi bahwa adanya kebijakan tersebut mampu meningkatkan harga impor komoditas pertanian, namun besarnya hanya sebesar $0,65 \%$. Hal ini membuktikan bahwa adanya kebijakan penurunan tarif mampu mengatasi permasalahan tersebut.

Penelitian ini bertujuan untuk menganalisis kemungkinan dampak yang ditimbulkan pada PDB, neraca perdagangan, kesejahteraan, terms of trade, nilai impor, nilai ekspor, pola perdagangan dunia, dan perubahan pada sektor tenaga kerja di Indonesia yang ditimbulkan dari adanya kebijakan pengenaan tarif dalam mengatasi permasalahan pada penurunan impor. Penelitian ini memasukkan kebijakan tarif sebesar $0 \%$ dan tarif sebesar 7,5\% untuk sektor pertanian di Indonesia dan melihat dampak yang ditimbulkan dari adanya kebijakan tersebut. Kontribusi dari penelitian ini adalah dapat melihat kebijakan mana yang cocok diterapkan di Indonesia ketika pengenaan tarif impor diberlakukan. Perbedaan penelitian ini dengan penelitian sebelumnya adalah dalam skema simulasi penerapan tarif yang diberlakukan dan pemilihan negara yang menjadi fokus penelitian. 
McEachern (2000) menjelaskan bahwa PDB merupakan jumlah nilai pasar dari barang dan juga jasa akhir yang diproduksi oleh sumber daya yang berada di dalam suatu negara selama jangka waktu tertentu, biasanya dalam satu tahun. Hal lainnya yang juga dapat diukur adalah kesejahteraan suatu negara yang merupakan salah satu ukuran perubahan dan untung atau ruginya kesejahteraan suatu negara (Rosyadi \& Widodo, 2018). Hicks (1939) mengatakan kesejahteraan merupakan perubahan pada kekayaan yang akan memiliki efek yang sama pada kesejahteraan konsumen, seperti halnya perubahan harga, dengan pendapatan tidak berubah.

Neraca perdagangan merupakan ukuran ekspor dan impor suatu negara. Tambunan (2011) menjelaskan bahwa tingginya utang luar negeri disebabkan adanya oleh tingginya defisit neraca perdagangan. Semakin rendahnya nilai ekspor dan tingginya nilai impor akan berdampak pada bertambahnya beban utang luar negeri sehingga dapat memperlemah kapasitas negara tersebut dalam pelunasan utang luar negerinya di dalam jangka panjang. Nilai ekspor merupakan total barang dan jasa yang dijual oleh suatu negara ke negara lainnya. Meier (1996) dalam Pinem (2009) menjelaskan bahwa ekspor merupakan salah satu sektor perekonomian yang memiliki peran penting dalam perluasan pasar. Sedangkan impor merupakan kegiatan memasukkan barang ke dalam daerah pabean.

Kopp (2020) menjelaskan bahwa terms of trade mencerminkan rasio antara harga ekspor dan harga impor suatu negara sehingga terms of trade merupakan salah satu indikator yang dapat digunakan untuk melihat kesehatan suatu negara terutama neraca pembayaran. Selain itu, penelitian juga melihat dampak terhadap pola perdagangan dunia melalui nilai perdagangan, volume perdagangan, dan kesejahteraan secara keseluruhan yang terjadi. Penelitian ini juga melihat dampak pada penyerapan tenaga kerja di Indonesia, baik pada penyerapan tenaga kerja terampil maupun tidak terampil.

Penelitian ini terbagi ke dalam enam bagian utama. Bagian pertama merupakan latar belakang penelitian. Bagian kedua menjelaskan tinjauan literatur dari penelitian sebelumnya. Bagian ketiga menjelaskan metode penelitian yang digunakan. Bagian keempat mencakup hasil dan diskusi. Bagian kelima merupakan kesimpulan dan implikasi kebijakan. Pada bagian enam memuat keterbatasan penelitian dan saran.

Hahn \& Pyun (2020) mengemukakan bahwa liberalisasi impor akan meningkatkan ekspor domestik. Tetapi tidak ditemukan hasil bahwa penurunan tarif impor ini menguntungkan ekspor negara eksportir. Hoque (2005) mengungkapkan bahwa pengurangan tarif impor akan berdampak positif terhadap PDB suatu negara, serta dalam jangka pendek akan menstimulasi pertumbuhan ekonomi suatu negara. Shagdar \& Nyamdaa (2017), dengan menggunakan model Computable General Equilibrium (CGE), mengemukakan bahwa dengan adanya reformasi tarif impor akan meningkatkan produksi dalam negeri, tetapi hal ini justru menyebabkan kerugian total kesejahteraan suatu negara dikarenakan kerugiannya lebih besar daripada keuntungan pada terms of trade. Selain itu, kenaikan tarif 
impor akan menurunkan nilai ekspor.

Elsheikh et al. (2015) menyatakan bahwa penurunan tarif impor akan meningkatkan impor gandum negara tersebut. Penelitian lainnya yang juga dilakukan oleh United Stated International Trade Commission (2009) menemukan bahwa dengan tidak adanya pengenaan tarif, maka perdagangan India dan Amerika Serikat akan meningkat sebesar 200-291 dolar Amerika Serikat. Li et al. (2018) juga melakukan kalibrasi model CGE untuk menghitung perubahan kesejahteraan yang terjadi akibat kenaikan tarif yang terjadi di Amerika Serikat dan Tiongkok. Hasil menunjukkan bahwa setiap peningkatan tarif impor sebesar 15\% oleh Amerika Serikat akan menyebabkan PDB Amerika Serikat meningkat dan PDB Tiongkok menurun.

Penurunan ekspor ke negara yang menerapkan tarif diikuti dengan peningkatan ekspor ke negara ketiga lainnya (Bown \& Crowley, 2007). Dong \& Whalley (2012) dan Chandra (2016) menyatakan bahwa fenomena defleksi terjadi untuk negara-negara ketiga lainnya. Noland et al. (2016) juga melakukan simulasi terkait kebijakan kenaikan tarif pada pemerintahan Presiden Donald Trump terhadap impor dari Tiongkok dan Meksiko. Studi ini menemukan bahwa di bawah simulasi perang dagang, lapangan pekerjaan akan turun lebih dari empat persen dengan dampak terbesar diderita oleh sektor jasa non-perdagangan. Meningkatnya pengangguran akan menyebabkan penurunan konsumsi dan investasi dalam negeri. Hipotesis dalam penelitian ini adalah adanya dampak positif terhadap PDB, neraca perdagangan, kesejahteraan, dan terms of trade, dan dampak negatif terhadap nilai impor, nilai ekspor, pola perdagangan dunia, dan penyerapan tenaga kerja yang ditimbulkan dari adanya kebijakan pengenaan tarif impor untuk sektor pertanian.

\section{Metodologi}

\subsection{Data}

Penelitian ini menggunakan Database Global Trade Analysis Project (GTAP) versi 9A dari Pusat Analisis Perdagangan Global, Universitas Purdue. Basis data mencakup 140 wilayah dan 57 sektor (Aguiar et al., 2016) dengan tahun referensi mencakup 2004, 2007, dan 2011 yang memungkinkan untuk menganalisis dampak dari adanya kebijakan tarif di berbagai sektor industri dan variabel makroekonomi di setiap wilayah. Tahun referensi terbaru digunakan dalam kalibrasi model.

\subsection{Agregasi}

Penelitian ini mengikuti pemetaan sektor basis GTAP dengan melakukan pemisahan lebih lanjut. Negara-negara dipetakan ke dalam pemetaan 1-ke-1 untuk masing-masing mitra dagang impor dan ekspor Indonesia. Beberapa pengelompokan wilayah juga dilakukan guna memasukkan negara pada kelompok yang 
sama. Pemetaan sektor juga dilakukan berdasarkan deskripsi sektor yang sama. Rincian agregasi dapat dilihat pada pengelompokan berikut:

Tabel 3: Agregasi GTAP

\begin{tabular}{cccc}
\hline \hline Negara & Wilayah & Agregasi Sektor & Agregrasi Faktor \\
\hline Indonesia & Oceania & Agriculture & Land \\
Tiongkok & EU_28 & Extraction & Unskilled Labor \\
Singapore & SSA (Sub Saharan Africa) & Processed Food & Skilled Labor \\
Japan & Other Country & TextWapp & Capital \\
Thailand & ROW (Rest of World) & Basic Manufacture & Natural Resources \\
Malaysia & & Metal Manufacture & \\
US & & Hightech Manufacture & \\
India & & Util_Cons & \\
& & Transport and Comunnication & \\
& & Other Service & \\
Sumber: Spesifikasi Database GTAP, 2020 & &
\end{tabular}

\subsection{Metode Simulasi}

Basis data GTAP dan model GTAP standar digunakan untuk menganalisis dampak dari kebijakan pengenaan tarif dan non-tarif pada sektor pertanian di Indonesia yang disebabkan oleh pengurangan impor pada sektor pertanian akibat peningkatan kasus COVID-19 di Indonesia. Model GTAP adalah model CGE multi-regional dan multi-sektor dengan persaingan sempurna dan skala hasil yang konstan. Model CGE adalah sistem persamaan matematika yang menggambarkan ekonomi secara keseluruhan dan interaksi antara agen-agennya. Perdagangan bilateral ditangani melalui asumsi Armington, yang menyediakan kemungkinan untuk membedakan impor dari negara mitra dan menjelaskan perdagangan intra-industri dari produk-produk serupa.

Studi ini menggunakan model CGE dengan asumsi skala hasil konstan dan pasar persaingan sempurna. Berikut dijelaskan arus melingkar dalam perekonomian daerah (lihat Gambar 3).

Brockmeier (2001) menjelaskan aliran melingkar adalah model visual ekonomi yang menggambarkan bagaimana rumah tangga dan bisnis berinteraksi melalui pasar untuk produk dan pasar sumber daya. Gambar 5 menjelaskan bahwa produksi akan menghasilkan perolehan dana yang dikembalikan ke rumah tangga dan kemudian akan kembali dibelanjakan untuk tiga sumber permintaan akhir. Sumber permintaan akhir terdiri dari belanja swasta, belanja pemerintah, dan tabungan yang akan diartikan sebagai investasi. Setiap sumber pengeluaran, serta pembelian barang setengah jadi akan terdiri dari pembelian domestik dan pembelian impor, sehingga menghasilkan penjualan domestik dan ekspor oleh perusahaan. Setiap negara akan melakukan impor tergantung dengan kebutuhan negaranya. Setiap wilayah memiliki struktur dan perlakuan fungsional yang sehingga akan menyebabkan negara memutuskan apakah membeli barang domestik atau luar negeri. Hal inilah yang disebut Armington Import Substitu- 


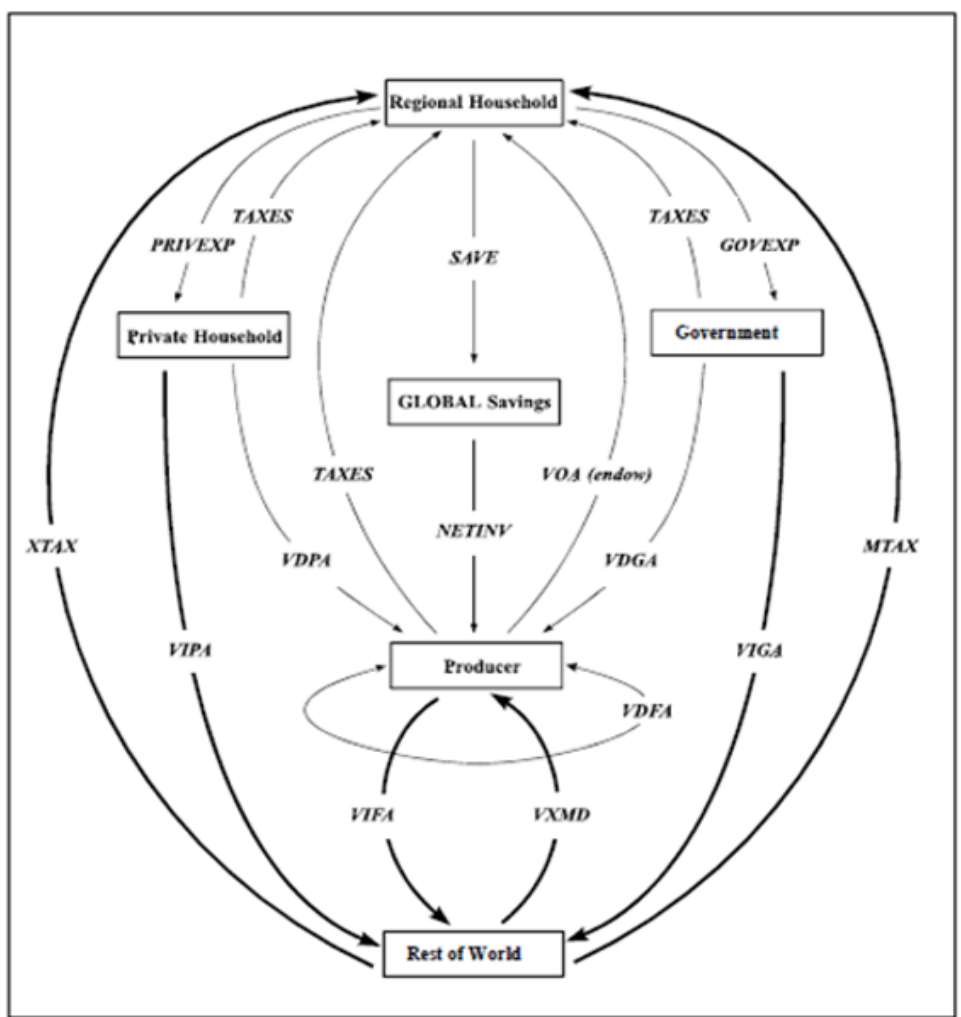

Gambar 5: Arus Melingkar Perekonomian Daerah Sumber: Brockmeier (2001)

tion karena diasumsikan barang bukanlah substitusi sempurna dengan barang lainnya.

Basis data digunakan dengan menggabungkan data perdagangan, transportasi, dan perlindungan bilateral terperinci yang menjadi ciri hubungan ekonomi antarwilayah, bersama dengan basis data input-output masing-masing negara, yang bertanggung jawab atas hubungan lintas sektoral. Analisis model CGE dianggap lebih unggul daripada pendekatan ekuilibrium parsial dalam kemampuannya untuk memberikan evaluasi ekonomi-luas alih-alih analisis terisolasi pada pasar atau sektor tertentu.

Perhitungan pada basis data dan model GTAP menggunakan perangkat lunak GEMPACK (General Equilibrium Modeling Package) (Harrison \& Pearson, 1996) yang dikembangkan oleh Pusat Studi Kebijakan, Victoria University, Melbourne, Australia. Dalam penelitian ini, perangkat lunak runGTAP digunakan untuk melakukan simulasi model. Penelitian ini menggunakan versi standar Model 
GTAP versi 6.2, versi terbaru setelah beberapa revisi mengenai berbagai masalah pemodelan (Hertel et al., 2001). Penelitian ini menggunakan metode Gragg's 4-6-8 steps solution dengan opsi "automatic accuracy" diaktifkan untuk memberikan akurasi hasil maksimal. Metode ini membagi guncangan dengan interpolasi menjadi peningkatan kecil dan mengulangi perhitungan beberapa kali.

\subsection{Simulasi}

Ada berbagai faktor dilakukannya simulasi kebijakan tarif di Indonesia. Salah satunya adalah penurunan impor sektor pertanian yang terjadi di Indonesia. Adapun simulasi kebijakan yang digunakan sebagai berikut:

1. Pengenaan tarif sebesar $0 \%$ terhadap impor sektor pertanian ke Indonesia, khususnya dari Tiongkok yang merupakan negara asal impor terbesar Indonesia.

2. Pengenaan tarif sebesar $7,5 \%$ terhadap impor sektor pertanian ke Indonesia, khususnya dari Tiongkok yang merupakan negara asal impor terbesar Indonesia.

Simulasi dengan menggunakan tarif $0 \%$ dan 7,5\% dilakukan guna melihat perbedaan pada besaran dampak yang ditimbulkan dan melihat simulasi kebijakan mana yang memiliki dampak positif terhadap Indonesia. Hal ini dilakukan guna pemilihan kebijakan yang baik dalam mengatasi dampak yang ditimbulkan dari adanya penurunan impor sektor pertanian di Indonesia. Pemilihan simulasi dengan tarif sebesar 7,5\% didasarkan pada Peraturan Menteri Keuangan (PMK) Nomor 199 Tahun 2019 yang memberlakukan kebijakan biaya masuk sebesar $7,5 \%$ untuk produk selain tekstil, tas, dan sepatu. Adanya aturan pengenaan tarif diharapkan dapat melindungi produsen dalam negeri. Sedangkan pemilihan simulasi dengan tarif sebesar $0 \%$ digunakan sebagai pembanding dengan kebijakan tarif sebesar 7,5\% dan merupakan batas bawah pengenaan tarif.

\section{Hasil dan Pembahasan}

Hasil dan diskusi menjelaskan dampak yang ditimbulkan akibat pengenaan tarif pada PDB, neraca perdagangan, kesejahteraan, terms of trade, nilai impor, nilai ekspor, perubahan lainnya pada perdagangan dunia, dan perubahan pada sektor tenaga kerja Indonesia.

\subsection{Dampak Makro Ekonomi}

Model GTAP memprediksi dampak negatif dari adanya pengenaan tarif sebesar $0 \%$ terhadap PDB Indonesia, sedangkan pengenaan tarif sebesar 7,5\% memiliki dampak positif bagi PDB Indonesia. Hal yang sebaliknya terjadi pada negara asal impor terbesar Indonesia, yakni Tiongkok yang mengalami peningkatan PDB berdasarkan simulasi pengenaan tarif sebesar $0 \%$ dan penurunan PDB 
berdasarkan simulasi pengenaan tarif sebesar 7,5\% (lihat Tabel 4). Maka dapat diketahui bahwa pengenaan sebesar 7,5\% akan mampu meningkatkan PDB negara yang mengenakan tarif, dan sebaliknya pengenaan tarif $0 \%$ pada impor akan menyebabkan penurunan PDB negara tersebut. Tarif sebesar 7,5\% dapat memberikan dampak positif pada PDB Indonesia dikarenakan adanya pengenaan tarif akan membatasi barang impor masuk, sehingga akan membantu produsen dalam negeri untuk dapat meningkatkan produksi dalam negeri yang nantinya akan dapat membantu dalam peningkatan PDB di Indonesia. Hal ini sejalan dengan penelitian yang dilakukan oleh Li et al. (2018) yang menyatakan bahwa setiap peningkatan tarif impor yang diberikan oleh suatu negara, maka akan meningkatkan PDB negara tersebut. Di sisi lain, penelitian yang dilakukan oleh Hoque (2005) mengungkapkan bahwa pengurangan tarif impor akan berdampak positif pada PDB suatu negara, serta dalam jangka pendek akan menstimulasi pertumbuhan ekonomi suatu negara. Perbedaan pada penelitian Hoque (2005) ini terletak pada simulasi kebijakan dan negara penelitian.

Tabel 4: Dampak terhadap Ekonomi Makro

\begin{tabular}{|c|c|c|c|c|c|c|}
\hline \multirow{2}{*}{ Negara } & \multicolumn{2}{|c|}{ PDB } & \multicolumn{2}{|c|}{ Trade Balance } & \multicolumn{2}{|c|}{ Equivalent Variation } \\
\hline & Simulasi 1 & Simulasi 2 & Simulasi 1 & Simulasi 2 & Simulasi 1 & Simulasi 2 \\
\hline Indonesia & $-0,0043$ & 0,0206 & $-9,9210$ & 58,428 & $-3,5153$ & 4,690 \\
\hline Tiongkok & 0,0007 & $-0,0046$ & 23,458 & $-140,985$ & 7,170 & $-4,228$ \\
\hline
\end{tabular}

Sumber: Hasil simulasi model GTAP (2020), diolah

Model GTAP juga memprediksi dampak negatif terhadap neraca perdagangan Indonesia ketika pengenaan tarif impor sebesar $0 \%$. Dengan tidak adanya pungutan tarif akan menguntungkan Tiongkok sebagai negara pengimpor terbesar di Indonesia. Tarif bukanlah satu-satunya faktor yang dapat secara langsung mempengaruhi nilai neraca perdagangan. Faktor lain juga dapat diketahui melalui nilai ekspor dan impor yang berubah dan nantinya akan mempengaruhi neraca perdagangan. Hasil menjelaskan bahwa nilai neraca perdagangan Tiongkok yang positif. Di sisi lain, ketika Indonesia mengenakan tarif impor sebesar 7,5\% maka akan menguntungkan Indonesia. Hal ini bisa dilihat dari nilai neraca perdagangan Indonesia yang menjadi positif. Sebaliknya, pengenaan tarif impor sebesar 7,5\% ini akan merugikan Tiongkok. Ini terlihat dari nilai neraca perdagangan Tiongkok yang sebesar $-140,985$. Oleh karena itu, dapat diketahui bahwa pengenaan tarif sebesar 7,5\% akan berdampak positif pada neraca perdagangan negara yang mengenakan tarif, dan sebaliknya pengenaan tarif sebesar $0 \%$ pada impor akan menyebabkan penurunan neraca perdagangan negara tersebut.

Hasil lain menjelaskan kesejahteraan negara dengan menggunakan equivalent variation sebagai ukuran perubahan dan untung atau ruginya kesejahteraan suatu negara. Model GTAP memprediksi pengenaan tarif sebesar $0 \%$ memiliki dampak negatif untuk Indonesia dan sebaliknya pengenaan tarif sebesar 7,5\% memberikan dampak positif bagi kesejahteraan Indonesia. Di sisi lain, simulasi pertama pada Tiongkok menjelaskan adanya dampak positif, namun sebaliknya 
pada simulasi kedua. Oleh karena itu, dapat disimpulkan dari data yang diperoleh bahwa pengenaan tarif sebesar 7,5\% akan lebih menguntungkan Indonesia dibandingkan dengan pengenaan tarif sebesar $0 \%$. Hal ini sejalan dengan penelitian Amiti \& Davis (2012) yang menyatakan bahwa perubahan tarif tertentu tergantung pada mode globalisasi perusahaan tempat seseorang bekerja dapat mempengaruhi kesejahteraan tenaga kerja melalui peningkatan upah pekerja.

\subsection{Dampak terhadap Perubahan Terms of Trade}

Dampak yang diprediksi dari adanya simulasi kebijakan menunjukkan pola yang juga sama pada perubahan PDB (lihat Tabel 5). Hasil simulasi menjelaskan bahwa pengenaan tarif sebesar $0 \%$ menyebabkan dampak negatif untuk Indonesia dengan nilai -0,0012 dan dampak positif pada simulasi kedua dengan nilai perubahan terms of trade sebesar 0,0066. Namun, hal sebaliknya terjadi pada Tiongkok yang merupakan negara asal impor terbesar Indonesia. Oleh karena itu, dapat diketahui bahwa adanya pengenaan tarif sebesar 7,5\% memberikan dampak positif bagi terms of trade Indonesia. Pengenaan tarif sebesar 7,5\% diperkirakan akan dapat meningkatkan rasio ekspor-impor. Nilai ekspor yang lebih tinggi dari nilai impor akan menyebabkan terms of trade suatu negara menjadi positif.

Tabel 5: Dampak terhadap Perubahan Terms of Trade

\begin{tabular}{ccccccc}
\hline \hline \multirow{3}{*}{ Negara } & \multicolumn{3}{c}{ Simulasi 1 } & \multicolumn{3}{c}{ Simulasi 2 } \\
\cline { 2 - 6 } & $\begin{array}{c}\text { Export } \\
\text { Price } \\
\text { Contribution }\end{array}$ & $\begin{array}{c}\text { Import } \\
\text { Price } \\
\text { Contribution }\end{array}$ & Change & $\begin{array}{c}\text { Export } \\
\text { Price } \\
\text { Contribution }\end{array}$ & $\begin{array}{c}\text { Import } \\
\text { Price } \\
\text { Contribution }\end{array}$ & $\begin{array}{c}\text { Change } \\
\text { Chand }\end{array}$ \\
\hline Indonesia & $-0,000796$ & 0,000019 & $-0,0012$ & 0,0067 & $-0,0001$ & 0,0066 \\
Tiongkok & 0,000128 & $-0,000025$ & 0,0004 & $-0,0013$ & 0,0002 & $-0,0022$ \\
\hline
\end{tabular}

Sumber: Hasil simulasi model GTAP (2020), diolah

Hasil simulasi lainnya juga menunjukkan bahwa perubahan dalam hal perdagangan dilihat dari kontribusi pada perubahan harga ekspor. Hasil yang ditampilkan memberikan prediksi bahwa pengenaan tarif sebesar 7,5\% mampu memberikan dampak positif dalam hal kontribusi pada perubahan harga ekspor jika dibandingkan dengan pengenaan tarif sebesar $0 \%$. Ini mungkin disebabkan karena peningkatan dalam permintaan ekspor negara.

\subsection{Dampak terhadap Nilai Impor dan Ekspor}

Model GTAP mampu memprediksi dampak pengenaan tarif untuk sisi impor pada suatu negara. Hal ini bisa dilihat dari simulasi yang disajikan dalam penelitian ini, yakni pengenaan tarif impor sebesar $0 \%$ akan berdampak positif terhadap nilai impor bagi Indonesia dan Tiongkok (lihat Tabel 6). Ini menandakan bahwa tidak adanya tarif akan meningkatkan jumlah barang yang diimpor oleh suatu negara. Sedangkan jika impor suatu negara dikenakan tarif sebesar 7,5\%, maka akan berdampak negatif pada Indonesia dan Tiongkok. Pengenaan 
tarif impor sebesar 7,5\% ini juga menunjukkan bahwa dampak negatif yang dirasakan Indonesia lebih besar jika dibandingkan dengan Tiongkok.

Burfisher (2021) berpendapat adanya defleksi terhadap barang-barang yang diproduksi di dalam negeri. Dikatakan bahwa karena barang impor akan mahal jika dikenakan tarif impor, maka negara dapat mengalihkan permintaan mereka terhadap barang-barang domestik dan menurunkan pasokan ekspor mereka. Hal ini tercermin dari nilai impor yang menurun ketika adanya pengenaan tarif sebesar $7,5 \%$.

Tabel 6: Dampak terhadap Nilai Impor dan Ekspor

\begin{tabular}{ccccc}
\hline \hline \multirow{2}{*}{ Negara } & \multicolumn{2}{c}{ Nilai Impor } & \multicolumn{2}{c}{ Nilai Ekspor } \\
\cline { 2 - 5 } & Simulasi 1 & Simulasi 2 & Simulasi 1 & Simulasi 2 \\
\hline Indonesia & 0,156188 & $-0,8585$ & 0,222043 & $-1,3629$ \\
Tiongkok & 0,034291 & $-0,2010$ & 0,255701 & $-1,5570$ \\
\hline Sumber: Hasil simulasi model GTAP (2020), diolah
\end{tabular}

Hasil lainnya juga menjelaskan bahwa pengenaan tarif impor sebesar $0 \%$ ternyata berdampak positif terhadap nilai ekspor Indonesia dan Tiongkok. Sebaliknya, ketika tarif impor dinaikkan menjadi 7,5\%, maka diperkirakan akan merugikan kedua negara. Tiongkok mengalami penurunan nilai ekspor yang lebih besar jika dibandingkan dengan Indonesia, yakni sebesar $-1,56$. Hal ini menandakan bahwa dengan penerapan tarif impor sebesar 7,5\% di Indonesia akan menurunkan kemampuan Tiongkok untuk mengekspor barang-barang, khususnya sektor pertanian.

\subsection{Dampak terhadap Perdagangan Dunia}

Hasil lainnya yang juga menjadi prediksi dalam model GTAP adalah perubahan yang terjadi pada pola perdagangan dunia (lihat Tabel 7). Hasil simulasi memprediksi bahwa equivalent variation untuk dunia mengalami penurunan baik dalam simulasi pertama maupun kedua, namun besaran penurunan lebih besar ketika pengenaan tarif sebesar 7,5\%. Dari sinilah dapat dikatakan bahwa adanya pengenaan tarif tidak menguntungkan bagi masyarakat seberapa pun besaran yang ditetapkan. Hal lain yang juga dilihat adalah perubahan pada nilai dan volume perdagangan dunia yang memiliki pola yang sama. Hasil simulasi menjelaskan bahwa pengenaan tarif sebesar 7,5\% secara keseluruhan memiliki dampak negatif terhadap perdagangan dunia melalui tingkat ekspor dan impor negara yang melakukan perdagangan dunia.

\subsection{Dampak terhadap tenaga kerja di Indonesia}

Perubahan lainnya yang juga dilihat adalah perubahan yang terjadi pada sektor tenaga kerja di bawah dua simulasi kebijakan yang diberlakukan (lihat Tabel 8). Hasil simulasi menunjukkan bahwa adanya pengenaan tarif sebesar 7,5\% mampu memberikan dampak negatif dalam hal penurunan penyerapan tenaga 
Tabel 7: Dampak Perubahan terhadap Perdagangan Dunia

\begin{tabular}{ccc}
\hline \hline Keterangan & Simulasi 1 & Simulasi 2 \\
\hline Equivalent Variation for World & $-0,4107$ & $-13,2024$ \\
Nilai perdagangan dunia & 0,000172 & $-0,0010$ \\
Volume perdagangan dunia & 0,000204 & $-0,0012$ \\
\hline \multicolumn{2}{l}{ Sumber: Hasil simulasi model GTAP (2020), diolah }
\end{tabular}

kerja terampil, tenaga kerja tidak terampil, dan modal. Secara keseluruhan dapat disimpulkan bahwa pengenaan tarif sebesar 7,5\% diperkirakan akan memberikan dampak negatif pada penurunan sektor tenaga kerja. Namun hasil lainnya juga menunjukkan bahwa pengenaan tarif sebesar $0 \%$ mampu memberikan dampak positif melalui peningkatan pada sektor tenaga kerja, baik tenaga kerja terampil dan tenaga kerja tidak terampil. Selain itu, pengenaan tarif sebesar $0 \%$ juga mampu memberikan dampak positif berupa peningkatan modal.

Tabel 8: Dampak Perubahan terhadap Tenaga Kerja di Indonesia

\begin{tabular}{llcc}
\hline \hline Keterangan & Contoh & Simulasi 1 & Simulasi 2 \\
\hline Tenaga kerja tidak terampil & $\begin{array}{l}\text { Pekerja toko, sektor pertanian, dan } \\
\text { lainnya } \\
\text { Tenaga kerja terampil }\end{array}$ & 0,0028 & $-0,0175$ \\
& $\begin{array}{l}\text { Manajer, pejabat, teknisi, dan } \\
\text { Asosiasi Profesional }\end{array}$ & 0,0002 & $-0,0001$ \\
Modal & Modal & 0,0001 & $-0,0006$ \\
\hline Sumber: Hasil simulasi model GTAP (2020), diolah & &
\end{tabular}

\section{Kesimpulan}

Penelitian ini melihat dampak yang ditimbulkan dari adanya pengenaan tarif impor pada sektor pertanian dengan menggunakan model GTAP standar. Penelitian ini melihat dampak yang ditimbulkan pada beberapa variabel ekonomi, seperti perubahan $\mathrm{PDB}$, neraca perdagangan, kesejahteraan, perubahan terms of trade, nilai impor, nilai ekspor, perdagangan dunia, serta perubahan pada sisi tenaga kerja Indonesia akibat simulasi kebijakan yang dilakukan.

Penelitian ini menggunakan simulasi kebijakan berupa pengenaan tarif sebesar $0 \%$ dan 7,5\% pada sektor pertanian sebagai akibat dari penurunan impor pertanian. Pengenaan tarif sebesar 7,5\% dimaksudkan oleh pemerintah untuk melindungi produsen dalam negeri. Hasil menjelaskan bahwa simulasi pertama dengan pengenaan tarif sebesar $0 \%$ mampu memberikan dampak positif pada nilai impor, nilai ekspor, perdagangan dunia dan sektor tenaga kerja. Hal ini dikarenakan pengenaan tarif sebesar $0 \%$ dapat membantu proses perdagangan antar negara semakin membaik. Namun, hal sebaliknya menjelaskan bahwa simulasi kedua dengan pengenaan tarif impor sebesar 7,5\% dapat memberikan dampak positif terhadap PDB, neraca perdagangan, kesejahteraan, dan terms of trade untuk Indonesia sebagai negara yang memberlakukan kebijakan tarif 7,5\%. 
Oleh karena itu, dapat disimpulkan bahwa kebijakan tarif sebesar $0 \%$ atau $7,5 \%$ yang diterapkan tergantung pada tujuan yang ingin diperoleh oleh suatu negara. Indonesia dapat meningkatkan PDB, neraca perdagangan, kesejahteraan, dan terms of trade dengan menggunakan kebijakan pengenaan tarif sebesar 7,5\%. Namun sebaliknya, jika Indonesia ingin meningkatkan nilai ekspor dan impor di Indonesia, maka pengenaan tarif sebesar $0 \%$ dapat menjadi pilihan kebijakan yang digunakan. Namun, dalam penelitian ini juga menunjukkan bahwa pengenaan tarif dapat menurunkan penyerapan tenaga kerja. Kondisi ini bisa disebabkan oleh faktor lain selain tarif yang mempengaruhi penyerapan tenaga kerja yang tidak dimasukkan ke dalam model penelitian.

\subsection{Keterbatasan Penelitian dan Saran}

Penelitian ini belum mampu melihat dampak langsung yang diakibatkan oleh pandemi COVID-19 dikarenakan data yang tersedia tidak merepresentasikan kondisi saat ini. Namun, penelitian ini mencoba menangkap dampak yang ditimbulkan akibat penurunan impor secara umum. Oleh karena itu, peneliti menyarankan peneliti selanjutnya untuk dapat memperluas kajian penelitian sehingga dapat merepresentasikan kondisi saat ini.

\section{Daftar Pustaka}

[1] Aguiar, A., Narayanan, B., \& McDougall, R. (2016). An overview of the GTAP 9 data base. Journal of Global Economic Analysis, 1(1), 181-208. doi: http:/ /dx.doi.org/10.21642/JGEA.010103AF.

[2] Amanta, F., \& Aprilianti, I. (2020). [Ringkasan kebijakan] Kebijakan perdagangan pangan Indonesia saat Covid-19. Center for Indonesian Policy Studies (CIPS) Indonesia. Diakses 28 Juli 2020. https://www.cips-indonesia.org/post/ ringkasan-kebijakan-kebijakan-perdagangan-pangan-indonesia-saat-covid-19.

[3] Amiti, M., \& Davis, D. R. (2012). Trade, firms, and wages: Theory and evidence. The Review of Economic Studies, 79(1), 1-36. doi: https://doi.org/10.1093/restud/rdr016.

[4] Badan Pusat Statistik. (2020a). Hasil survei sosial demografi dampak Covid-19 2020.

[5] Badan Pusat Statistik. (2020b). Ekspor-impor: Perdagangan luar neger. Diakses 5 Agustus 2020. https://www.bps.go.id/subject/8/ekspor-impor.

[6] Brockmeier, M. (2001). A graphical exposition of the GTAP model. GTAP Technical Paper, 8. Diakses 5 Agustus 2020. https:/ / www.gtap.agecon.purdue.edu/resources/ download/181.pdf.

[7] Bown, C. P., \& Crowley, M. A. (2007). Trade deflection and trade depression. Journal of International Economics, 72(1), 176-201. doi: https://doi.org/10.1016/j.jinteco.2006.09.005.

[8] Burfisher, M. E. (2021). Introduction to computable general equilibrium models (3rd edition). Cambridge University Press.

[9] Chandra, P. (2016). Impact of temporary trade barriers: Evidence from China. China Economic Review, 38, 24-48. doi: https://doi.org/10.1016/j.chieco.2015.11.002.

[10] Dong, Y., \& Whalley, J. (2012). Gains and losses from potential bilate- 
ral US-China trade retaliation. Economic Modelling, 29(6), 2226-2236. doi: https://doi.org/10.1016/j.econmod.2012.07.001.

[11] Elsheikh, O. E., Elbushra, A. A., \& Salih, A. A. (2015). Economic impacts of changes in wheat's import tariff on the Sudanese economy. Journal of the Saudi Society of Agricultural Sciences, 14(1), 68-75. doi: https://doi.org/10.1016/j.jssas.2013.08.002.

[12] Fugazza, M. (2020). Impact of the COVID-19 pandemic on commodities exports to China. UNCTAD Research Paper 44. United Nations Conference on Trade and Development. doi: https://doi.org/10.18356/93ebf4d1-en.

[13] Hahn, C. H., \& Pyun, J. H. (2020). Does home (output) import tariff reduction increase home exports? Evidence from Korean manufacturing plant-Product data. ERIA Discussion Paper Series 315. Economic Research Institute for ASEAN and East Asia. Diakses 28 Juli 2020. https://www.eria.org/publications/ does-home-output-import-tariff-reduction-increase-home-exports-evidence-fromkorean-manufacturing-plantproduct-data/.

[14] Harrison, W. J., \& Pearson, K. R. (1996). Computing solutions for large general equilibrium models using GEMPACK. Computational Economics, 9(2), 83-127. doi: https://doi.org/10.1007/BF00123638.

[15] Hertel, T. W., Walmsley, T., \& Itakura, K. (2001). Dynamic effects of the "new age" free trade agreement between Japan and Singapore. Journal of Economic Integration, 16(4), 446-484. doi: https://doi.org/10.11130/jei.2001.16.4.446.

[16] Hicks, J. R. (1939). Value and capital: An inquiry into some fundamental principles of economic theory. Clarendon Press.

[17] Hoque, S. (2005). The impact of tariff reduction on Bangladesh economy: a computable general equilibrium assessment. MPRA Paper 16246. Munich Personal RePEc Archive. Diakses 28 Juli 2020. https://mpra.ub.uni-muenchen.de/16246/.

[18] Kementerian Pertanian. (2020). Basisdata ekspor-impor komoditi pertanian. Diakses 28 Juli 2020. http:/ / database.pertanian.go.id/eksim/index1.asp.

[19] Kopp, M. C. (2020, 30 June). Terms of trade (TOT). Investopedia.com. Diakses 28 Juli 2020. https:/ / www.investopedia.com/terms/t/terms-of-trade.asp.

[20] Li, C., He, C., \& Lin, C. (2018). Economic impacts of the possible China-US trade war. Emerging Markets Finance and Trade, 54(7), 1557-1577. doi: https://doi.org/10.1080/1540496X.2018.1446131.

[21] McEachern, W. A. (2000). Ekonomi makro: Pendekatan kontemporer. Salemba Empat.

[22] McKibbin, W., \& Fernando, R. (2020). The global macroeconomic impacts of COVID-19: Seven scenarios. Asian Economic Papers, [Just Accepted], 1-55. doi: https://doi.org/10.1162/asep'a'00796.

[23] Noland, M., Robinson, S., \& Moran, T. (2016). Impact of Clinton's and Trump's trade proposals. In M. Noland, G. C. Hufbauer, T. Moran, \& S. Robinson, PIIE Briefing: 16-6 Assessing trade agendas in the US presidential campaign, pp. 17-39. Diakses 28 Juli 2020. https://www.piie.com/system/files/documents/piieb16-6.pdf.

[24] Pinem, J. R. (2009). Analisis pengaruh ekspor, impor, kurs nilai tukar rupiah terhadap cadangan devisa Indonesia (Skripsi, Universitas Sumatera Utara).

[25] Rosyadi, S. A., \& Widodo, T. (2018). Impact of Donald Trump's tariff increase against Chinese imports on global economy: Global Trade Analysis Project (GTAP) model. Journal of Chinese Economic and Business Studies, 16(2), 125-145. doi: 10.1080/14765284.2018.1427930.

[26] Shagdar, E., \& Nyamdaa, O. (2017). Impacts of import tariff reforms on Mongolia's economy: CGE analysis with the GTAP 8.1 data base. The Northeast Asian Economic 
Review, 5(1), 1-25.

[27] Tambunan, T. T. H. (2011). Perekonomian Indonesia: Kajian teoretis dan analisis empiris. Ghalia Indonesia.

[28] United Stated International Trade Commission. (2009). The year in trade 2008: Operation of the trade aggrements program [60th report]. USITC Publication 4091. Washington, DC. https://www.usitc.gov/publications/332/pub4091_0.pdf.

[29] WITS. (2020). Ekspor dan Impor. World Integrated Trade Solution. Diakses 02 Agustus 2020. https://wits.worldbank.org/. 
this page intentionally left blank 